\title{
Study on the Construction and Evaluation of College English Effective Classroom Environment
}

\author{
Youping $\mathrm{Xu}^{1, \text { a }}$ \\ ${ }^{1}$ School of Foreign Languages, Neijiang Normal University, Neijiang, Sichuan, 641112
}

Keywords: College English, Effective Classroom, Environment Construction

\begin{abstract}
College English is an important compulsory educational basic course for the college students . Its ultimate objective is to improve the students' English application ability and improve the students' comprehensive quality. In college English courses, constructing the effective classroom to improve the quality of the entire curriculum has a decisive significance of college English teaching. As an improvement and sublimation of high school English learning, college English courses have undertaken the task of cultivating the English comprehensive applied ability of students to adjust to the developmemt of economy and the international communication. College English will lay an important foundation for students who are preparing for attending the post-graduate examination and studying abroad. Combined with the relevant concepts of effective classroom, the paper analyzes the theoretical framework of the effective classroom construction and its evaluation standard of college English effective classroom environment construction and puts forth the way to carry out the construction and evaluation of college English effective classroom environment to improve the students’ English application ability.
\end{abstract}

\section{Introduction}

Since the sixties of last century, effective teaching has been paid more and more attention by domestic and foreign scholars. The researches on effective teaching has become a hot issue in the education sector. As a key place to learn knowledge, the classroom teaching environment is an unneglecting factors in the improvement of teaching while students, as the main body of studying, plays a very important role in the improvement of teaching. The construction of college English effective classroom environment is inseparable from the teaching process and effective teaching theory.

Therefore, to improve the quality of classroom teaching and enhance the evaluation of the effective classroom environment to realize effective teaching plays a huge positive role in developing students' English application ability. In recent years, the researches on the construction and evaluation of the effective classroom environment of college English in China has had a good start. Many educational scholars have provided a lot of research results on how to promote effective classroom construction in theory and research methods. However, the researches have a lot of deficiencies. Some researches have not formed the theoretical framework of the construction of effective classroom teaching in foreign language environment nor taken into consideration of the interactive relationship between the theoretical framework and the evaluation methods. Combined with the relevant concepts of effective classroom , the paper analyzes the theoretical framework of the effective classroom construction and its evaluation standard of college English effective classroom environment construction and puts forth the way to carry out the construction and evaluation of college English effective classroom environment to improve the students' English application ability.

\section{Analysis of the Concept of Constructing College English Effective Classroom}

Effective teaching is a dynamic development concept and its connotation continues to expand with the development of the values of teaching and teaching theory and teaching research methods. Effective teaching requires two essential elements, namely including appropriate teaching skills and related teaching activities and the use of specific teaching context. There are many factors that affect effective teaching, which is related to the management of classroom and the innovation of 
classroom activities and the implementation of education technology.

Thus, effective teaching must be based on the creation of appropriate teaching context and teaching skills and teaching activities. The different teaching situation requires teachers to adopt flexible classroom management strategies so that teaching activities can be effectively carried out. In order to meet the requirements of the creation of the situation, teachers plays a leading role in teaching interaction. Throughout the whole activities, teachers should constantly guide students to explore knowledge and ensure that activities have a good innovation and exchanges can be actively carried out and different ideas can be mutually discussed [2]. Moreover, the use of appropriate educational techniques in teaching activities plays an important role in the effective development of the whole activities, which is of great help to improve the quality of teaching and to meet the specific requirements of students in different situations.

Effective and reasonable teaching concept, students' learning behaviors, interpersonal and environmental support will promote the construction of $t$ effective classroom environment. The teachers' teaching concept and teaching behaviors plays a decisive role in the learning effect of students, which affect the students' perception and emotional development of the situation. The effective classroom environment has two advantages: the first is to discover the characteristics of the educational environment through the experience of the participants in the classroom activities and the perceived perception of the situation; second is to capture some important information that the researchers have neglected through the external observation [3]. Although to a certain extent, the teacher's daily teaching behavior is inconsistent, but students can learn through a longer period of time to make an accurate judgment of the classroom environment.

In the context of foreign language learning, classroom learning is not only the cognitive process of learning, but also the process of communicating ideas and establishing a social relationship with students through participation in classroom activities. The teaching goal of college English in our country is to cultivate students' English communication ability. Through some enlightening and exploring teaching activities, teachers will actively guide the students to take the initiative to study and enhance the students' interest in English learning and create an independent and positive innovation for students.

The effective teaching, to a large extent, can not only improve the students' comprehensive application of English ability but also improve the students' autonomous learning ability, and comprehensively enhance the students' comprehensive cultural quality, and constantly cultivate a number of well-trained professional talents for the development of country and international exchange of [4].

To sum up, the effectiveness of the English classroom is inseparable from the outstanding teaching skills and teaching activities and the appropriate teaching situation. And, in the teaching activities, students and teachers are the main body of teaching, not only the teacher is the main speaker of teaching, students in the classroom also plays an important role. The implementation of teaching skills, the efficient development of teaching activities and the rational construction of teaching situations are closely linked with harmonious and orderly interpersonal relationships.

\section{The Evaluation of College English Effective Classroom Environment Construction}

To produce effectiveness of the whole classroom teaching, the specific evaluation cannot be separated from two important aspects: the results of teaching and teaching process. Thus, the evaluation of the effective classroom environment for college English should be evaluated from both the teaching process and the results of teaching. It not only evaluates whether the classroom environment constructed in the student learning process is effective, but also ensures what learning effect students have obtained after studying in the classroom environment [5].

The quality of teaching standards is divided into promissory standard degree and satisfactory degree. The promissory standard degree is mainly to meet the pre-set education and teaching standards, according to the concept of college English effective classroom environment to determine the concept of classroom construction dimensions, that is, the perception of students' teaching behavior, interpersonal relationship and teaching environment and the evaluation of effectiveness of 
classroom learning process. The satisfactory degree refers to satisfaction that students have obtained after the effect of classroom teaching experience. The two standards are very important in evaluating the effectiveness of classroom learning results.

In a large number of empirical studies follow Moos (1979) proposed by the human and environmental interaction theory and the specific division of the dimension, resulting in a variety of classroom environment scale. It is mainly used to explore the relevance of classroom environment and learning outcomes, as a standard variable to assess teaching innovation or to improve the learning environment in teaching practice. Several ways, such as "Classroom environment standard", "learning environment scale", "personalized classroom environment questionnaire", "classroom situation questionnaire", "classroom environment scale" and "education technology to help focus on the results of learning environment scale", are compared from the commonly used scale [6].

For example, WIHIC is a combination of the most prominent relevant factors in the previous questionnaire, which is the most widely used, including the seven factors : student cohesiveness , teacher support, involvement, inquiry, task orientation, cooperation, and equality. At the level of the evaluation of the process, the dimension of the construction of a college English effective classroom environment is divided into the main axis, and the twelve factors are chosen as the standard of the evaluation of the effective classroom environment of college English. Among them, learning behavior includes six factors: task orientation, activity participation, inquiry learning, cooperative learning, personalized learning and practical connection. The context support dimension also includes three factors: classroom management, activity innovation and multimedia technology.

In the results of the evaluation point of view, according to the "Test of Science related attitude scientific curriculum attitude test" and " Scales of Students Personal Perception of the classroom Climate," the construction standard of college English effective classroom environment lies in students' learning interest, harvest evaluation and self-efficacy. The three important standard reflect students' satisfaction degree to college English effective classroom teaching.

\section{The Establishment of Theoretical Model}

College English effective classroom environment construction and the evaluation of the theoretical model not only take into account the teaching process but also consider the results of teaching. In the process of teaching, the construction of college English effective classroom environment is based on the effective teaching theory. The learning behaviors, interpersonal support and situational support of students has a great help to promote the construction of college English effective classroom environment and can ultimately confirm its evaluation standard.[8] The results learning that students has gained will promote them to throw themselves into study and actively take part in various activities, in reverse, these behaviors promote the development of the effective teaching of college English. So the implementation of teaching skills, the concrete development of teaching activities, the coordination of interpersonal relationships and the creation of teaching situations will play a very important part in the effectiveness of college English classroom teaching.

\section{The Way to Build College English Effective Classroom Environment}

At present, with the dramatic development of science and technology, net and multimedia technology has been widely used in English teaching and provides room and the opportunity to construct effective college English teaching environment. The traditional teaching approach, based on teacher-centred, has many defects and has seriously influenced the activeness and learning results of students. So with the help of net and multimedia, the teacher should construct college English effective classroom environment to improve students' English level. The way is as fallowing:

1. Changing traditional teaching approach, providing rich teaching materials

In English course, the teachers should change the traditional approach and focuses on the students , 
the main body of study. The teacher should pay attention to the selection of teaching method and the teaching content. For one thing, the teachers can load some proper information from Internet and provide them to students to study, for another thing, the teachers also ask students to surf the Internet to find the assigned materials to make a good prepare for the study in class. The way can change boring and rigid teaching content and stimulate students' learning motivation, which lay down a good foundation for classroom teaching. The change of teaching approach and the constantly enriched teaching content will enhance students' learning interest and promote them to attend classroom activities. This is the foundation of setting effective classroom environment. Otherwise teachers can insert English speech Video of foreign famous characters and play some topic-related films in teaching to relax physical and mental nerves and produce very good results.

\section{Designing various activities to promote students to attend them}

Effective classroom teaching can neglect the participation of students. Students' active participation will determine the success of the courses. The teacher will design effective classroom activities to stimulate students to discuss their ideas and train their spoken ability and writing ability. The teachers can divide the students into several groups and select a leader for each group. In class, each group will discuss the assigned topic, such as "How I spend my spare time" "How science and technology have changed our life" or "My view on Internet ( cell phone , cars , TV etc.)”. During the discussion, the teachers will guide the students to find the topic to develop the discussion. Of course, the learning effectiveness is very important. The teachers will know the learning difficulty of students and give them timely help. Besides studying, the teachers will concern about the psychological elements to promote them to study hard. The teachers will give some advice to them on how to study and how to have a meaningful life in college. Finding a good way to learn and improving study is very useful. Whether in knowledge or in the rich experience, the teacher can provide appropriate guidance. The teachers can apply a set of suitable learning methods for students, and students should learn to actively adapt to the teacher's way. In this way, students can find learning interest and take part in classroom activities. Finally the students can gain the effective learning results from the effective classroom environment.

\section{Reflecting the teaching results and evaluating teaching}

After having courses, the teachers will have a reflection on their teaching results and make an evaluation on teaching. They can analyze the teaching results by students' performance and the communication with students. Through the reflections, the teachers can know whether they have applied effective teaching skills and classroom activities or they set up effective teaching environment to find a good way to construct effective college classroom environment. They may write down their thoughts and have a sum of their teaching. On in this way can teachers realize the goal to construct effective classroom teaching environment and improve students' English.

\section{Conclusion}

Classroom teaching is a vital part of the whole learning process. The effective teaching classroom environment directly determines the quality of teaching. In the specific teaching, the reasonable and effective teaching theory are the basis. Students' participation in specific teaching activities to master knowledge, students' learning behaviors, interpersonal support and situational support is an effective part of the construction of college English classroom . The construction and evaluation of college English effective classroom environment have reflected the urgent demand of the current reform of college English teaching. To realize the object, college English teachers should change their teaching concept and study the latest educational theory to improve teaching. By keeping on study teaching theory and teaching approaches, teachers will really improve the quality of college English teaching. 


\section{Acknowledgements}

This study was conducted by Neijiang Normal University the teach reform project: Art College English classroom teaching "five support items" - based on "cooperative learning" model "funding, project number: JG201517-295.

\section{References}

[1] Wang Chao. College English effective classroom teaching environment investigation and analysis - a general college in Xinjiang as a target case study [J]. Journal of Changji University, 2016, (06): 97-101.

[2] Tingqin Qin, Wang Ting. Research on the Localization of Effective English Classroom Teaching in College English in Xinjiang under the Information Environment -Taking Xinjiang Agricultural University as an example [J]. Journal of Changji University, 2015, (05): 75-79.

[3] Guo Hang. Theoretical framework for the construction and evaluation of effective classroom environment in college English [J]. Knowledge Economy, 2014, (20): 144.

[4] Qu Xin, Wang Chenglin. Study on the Cooperation of Chinese and Foreign Teachers Based on the Construction of University English Quality Classroom Environment [J]. Contemporary Foreign Language Research, 2014, (05): 33-36 + 77.

[5] Shao Qinyu, He Li. Construction and empirical research of cooperative learning model based on network and classroom environment [J]. Foreign Language Teaching, 2014, (02): 31-35 + 47.

[6] Chen Yun, Wang Zhiguo. The basis of teachers and students interactive cooperation in the ecological college English classroom teaching environment construction [J]. Journal of Higher Correspondence, 2011, (09): 61-63.

[7] Feng Yufang, Cai Ling. Multi-media network environment under the college English comprehensive curriculum research classroom teaching model construction [J]. Foreign Language and Foreign Language Teaching, 2009, (11): 28-31.

[8] Yang Shanjiang. The construction of multimedia network environment under the college English classroom teaching evaluation system [J]. Journal of Jilin Normal University, 2008, (05): 21-24. 